\title{
PEMBERIAN IMUNISASI HEPATITIS B (PASIF) PADA BAYI YANG LAHIR DARI IBU HBsAg POSITIF
}

\section{THE GIVENESS OF HEPATITIS B IMMUNIZATION (PASSIVE) IN BABY BORNS TO HBSAg MOTHERS}

\author{
Ramadhani A. K. $S^{1}$, Juniastuti ${ }^{2}$, Muhammad Ardian C. L. ${ }^{2}$
}

1. Program Studi Pendidikan Bidan, Fakultas Kedokteran, Universitas Airlangga Surabaya

2. Fakultas Kedokteran, Universitas Airlangga

Alamat korespondensi:

Jl. Mayjen Prof. Dr. Moestopo No.6-8, Airlangga, Kec. Gubeng, Surabaya, Indonesia Email: hanny.kusumasary@gmail.com

\begin{abstract}
Abstrak
Latar Belakang: Berdasarkan data Dinas Kesehatan Kota Surabaya tercatat 748 bayi lahir dari ibu dengan HBsAg positif diseluruh wilayah puskesmas kota Surabaya. Penelitian ini bertujuan untuk mengetahui pemberian imunisasi hepatitis B (pasif) pada bayi yang dilahirkan dari ibu dengan HBsAg positif di 4 wilayah puskesmas di Kota Surabaya. Metode: Penelitian ini menggunakan deskriptif observasional dan teknik total sampling dengan pendekatan cross-sectional. Sampel yang memenuhi kriteria inklusi sebanyak 56 bayi. Variabel yang diamati meliputi pemberian imunisasi hepatitis B (pasif) pada bayi yang dilahirkan dari ibu dengan HBsAg positif. Analisis data menggunakan univariat atau deskriptif. Hasil: Didapatkan distribusi pemberian imunisasi pasif hepatitis B (HBIG) pada bayi sebanyak $91,1 \%$ dan 40 bayi $(71,4 \%)$ dinyatakan non reaktif saat mereka berusia $>9$ bulan. Kesimpulan: Hampir seluruh bayi yang lahir dari ibu dengan HBsAg melakukan imunisasi pasif (HBIG) dan imunisasi aktif (HB-0) tepat waktu dan sebagian besar bayi dinyatakan non reaktif terhadap HBsAg saat berusia lebih dari 9 bulan.
\end{abstract}

Kata kunci : Imunisasi, HBIG, Hepatitis B, HBV, HBsAg, Pemberian, Surabaya

\begin{abstract}
Background: Based on data from the Surabaya City Health Office, 748 infants born to HBsAg positive mothers in all of the public city health center of Surabaya. This study aims to describe the giveness hepatitis B immunization (passive) in infants born to HBsAg positive mothers in 4 of the public city health center in Surabaya. Method: This study uses descriptive observational study and total sampling technique with a cross-sectional approach. All samples which is included to inclusion criteria were 56 infants. The variables observed the giveness of hepatitis B immunization (passive) in infants born to HBsAg positive mothers and the HBsAg status of the children after hepatitis $B$ immunization which were performed when they were more than 9 months old. Univariate or descriptive analysis was performed. Results: The study found the distribution frequency the giveness of passive hepatitis B immunization (HBIG) were $91,1 \%$ and the HBsAg status when the children more than 9 months old were $71,4 \%$ are declared as non-reactive to HBsAg.. Conclusion: Almost all infants born to HBsAg postive mothers have gone through passive immunization (HBIG) and most of them are found to be non-reactive to HBsAg when they are more than 9 months old.
\end{abstract}

Keywords: Immunization, HBIG, Hepatitis B, HBV, HBsAg, The giveness, Surabaya 


\section{PENDAHULUAN}

Penyakit hepatitis B masih merupakan masalah kesehatan utama di seluruh dunia. Di dunia, pengidap hepatitis B telah mencapai 2 milyar penderita dengan 240 juta penderita diantaranya menjadi pengidap hepatitis B kronik. Negara Indonesia menduduki peringkat kedua di negara South-East Asia Region (SEAR) setelah negara Myanmar yang termasuk golongan negara dengan tingkat endemisitas hepatitis B sedang sampai tinggi ( $>8 \%)$. Di Indonesia telah ditemukan penderita infeksi Hepatitis B Virus (HBV) maupun kronik sebesar 25-50\% dengan penularan secara vertikal Mother-to-child Transmision (MTCT) dan didapatkan prevalensinya sekitar 2,5-10\% (Yano et al., 2015). Pada salah satu penelitian mengenai prevalensi HBsAg pada ibu hamil tahun 2003 ditemukan di Jakarta sebesar 2,2\% dan di Bali sebesar 1,9\% yang kemudian terjadi peningkatan prevalensi HBsAg pada tahun 2016 di Jakarta, Jawa Barat, dan Bali masing-masing sebesar 5,2\%, 4,7\%, dan 2,6\% (Lusida, et al., 2016).

Kurangnya pemahaman masyarakat tentang penyakit hepatitis B beserta gejalanya yang terkadang tidak disadari menyebabkan kurangnya kesadaran masyarakat akan pentingnya skrining HBsAg pada ibu hamil sehingga upaya pencegahan penyakit virus hepatitis B seperti pemberian imun HBIG pada bayi, pemberian imunisasi hepatitis B lengkap maupun cakupan pemeriksaan $\mathrm{HBsAg}$ pada ibu hamil masih belum merata dan belum maksimal. Bila bayi diberikan imunisasi pasif hepatitis B yaitu HBIG bersamaan dengan imunisasi hepatitis B-0 disisi tubuh bayi yang berbeda dalam waktu 12 jam setelah lahir maka dapat memberikan perlindungan yang efektif $85 \%$ hingga $95 \%$ dalam mencegah infeksi virus hepatitis B dan kronisitas dari ibu ke bayinya. Namun apabila bayi hanya diberikan imunisasi hepatitis B saja tanpa HBIG maka efektivitas perlindungannya sekitar 75\% dan pemberian ketiga dosis imunisasi hepatitis B (HB-1, HB-2, HB-3) dengan dosis yang sesuai rekomendasi dapat membentuk respons protektif pada $>90 \%$ dewasa, bayi, anak, dan remaja (IDAI, 2011).

Dinas Kesehatan Kota Surabaya pada tahun 2017 melaporkan bahwa kasus hepatitis B di Kota Surabaya sebanyak 1.154 kasus dengan jumlah penderita pria 234 jiwa dan penderita wanita 920 jiwa. Jumlah kasus hepatitis B sangat bervariasi pada setiap wilayah puskesmas di Surabaya. Dua wilayah puskesmas yang terdapat 
kasus hepatitis B terbesar diantaranya Puskesmas Gading (49 kasus) dan Puskesmas Simomulyo (45 kasus). Sedangkan dua wilayah puskesmas yang termasuk wilayah rendah kasus hepatitis B berada di Puskesmas Made (7 kasus) dan Puskesmas Gayungan (7 kasus).

Tujuan dari penelitian ini untuk memperoleh gambaran pemberian imunisasi hepatitis B (pasif) pada bayi yang dilahirkan dari ibu dengan HBsAg positif di 4 wilayah puskesmas di Surabaya tahun 2017.

\section{METODE}

Rancangan penelitian yang digunakan adalah cross sectional. Populasi pada penelitian ini adalah seluruh bayi yang dilahirkan dari ibu dengan HBsAg positif di 4 wilayah puskesmas di Surabaya yaitu Puskesmas Gading, Puskesmas Simomulyo, Puskesmas Made, dan Puskesmas Gayungan dengan jumlah 61 bayi. Teknik sampel yang digunakan adalah total sampling. Besar sampel didapat berdasarkan kriteria inklusi sebanyak 56 sampel.

Variabel dalam penelitian ini adalah pemberian imunisasi hepatitis B (pasif) imunisasi hepatitis B (pasif), dan status HBsAg anak yang dilahirkan dari ibu dengan HBsAg positif pasca imunisasi hepatitis B (pasif) saat berusia $>9$ bulan. Berikut definisi operasional dan variabel penelitian.

Tabel 1 Definisi operasional variabel penelitian

\begin{tabular}{|c|c|c|c|}
\hline Variabel & Definisi Operasional & Alat Ukur & Kategori \\
\hline $\begin{array}{l}\text { Pemberian imunisasi } \\
\text { pasif hepatitis B } \\
\text { yaitu HBIG }\end{array}$ & $\begin{array}{l}\text { HBIG merupakan imun yang } \\
\text { diberikan pada bayi yang dilahirkan } \\
\text { dari ibu dengan HBsAg positif berisi } \\
\text { sediaan anti HBs dalam titer tertinggi } \\
\text { saat lahir (Surya, 2017) }\end{array}$ & $\begin{array}{l}\text { Rekam medis } \\
\text { puskesmas dan data } \\
\text { Dinas Kesehatan Kota } \\
\text { Surabaya }\end{array}$ & $\begin{array}{l}\text { 1. Ya } \\
\text { 2. Tidak }\end{array}$ \\
\hline $\begin{array}{l}\text { Status HBsAg pada } \\
\text { bayi pasca imunisasi } \\
\text { hepatitis B (pasif) }\end{array}$ & $\begin{array}{l}\text { Status HBsAg pada bayi yang } \\
\text { dilahirkan dari ibu dengan HbsAg } \\
\text { positif (usia }>9 \text { bulan) setelah } \\
\text { imunisasi hepatitis B (pasif) }\end{array}$ & $\begin{array}{l}\text { Rekam medis } \\
\text { puskesmas dan data } \\
\text { Dinas Kesehatan Kota } \\
\text { Surabaya } \\
\text { (Uji HBsAg } \\
\text { menggunakan Rapid } \\
\text { Test SD BIOLINE - } \\
\text { PT Indofarma, TBK) }\end{array}$ & $\begin{array}{l}\text { 1. Reaktif } \\
\text { 2. Non Reaktif }\end{array}$ \\
\hline $\begin{array}{l}4 \text { Wilayah } \\
\text { puskesmas di } \\
\text { Surabaya }\end{array}$ & $\begin{array}{l}\text { Wilayah puskesmas tinggi kasus } \\
\text { hepatitis B : } \\
\text { - Puskesmas Gading } \\
\text { - Puskesmas Simomulyo } \\
\text { Wilayah puskesmas rendah kasus } \\
\text { hepatitis B : } \\
\text { - Puskesmas Made }\end{array}$ & $\begin{array}{l}\text { Rekam medis } \\
\text { puskesmas dan data } \\
\text { Dinas Kesehatan Kota } \\
\text { Surabaya }\end{array}$ & - \\
\hline
\end{tabular}


Pengumpulan data dilakukan pada bulan Februari - April 2019 dimulai dengan perijinan penelitian kemudian peneliti mendapatkan daftar nama bayi yang lahir dari ibu dengan HBsAg positif periode Januari - Desember 2017 dari Dinas Kesehatan Kota Surabaya dan rekam medis puskesmas terkait. Untuk menentukan sampel penelitian dilakukan seleksi data sesuai dengan kriteria inklusi dan eksklusi. Kemudian data dari rekam medis dikumpulkan. Setelah data terkumpul, dilakukan pengolahan dan analisis data yang akan disajikan dalam bentuk tabel, diagram dan narasi.

\section{HASIL DAN PEMBAHASAN}

\section{Pemberian Imunisasi Pasif Hepatitis B (HBIG)}

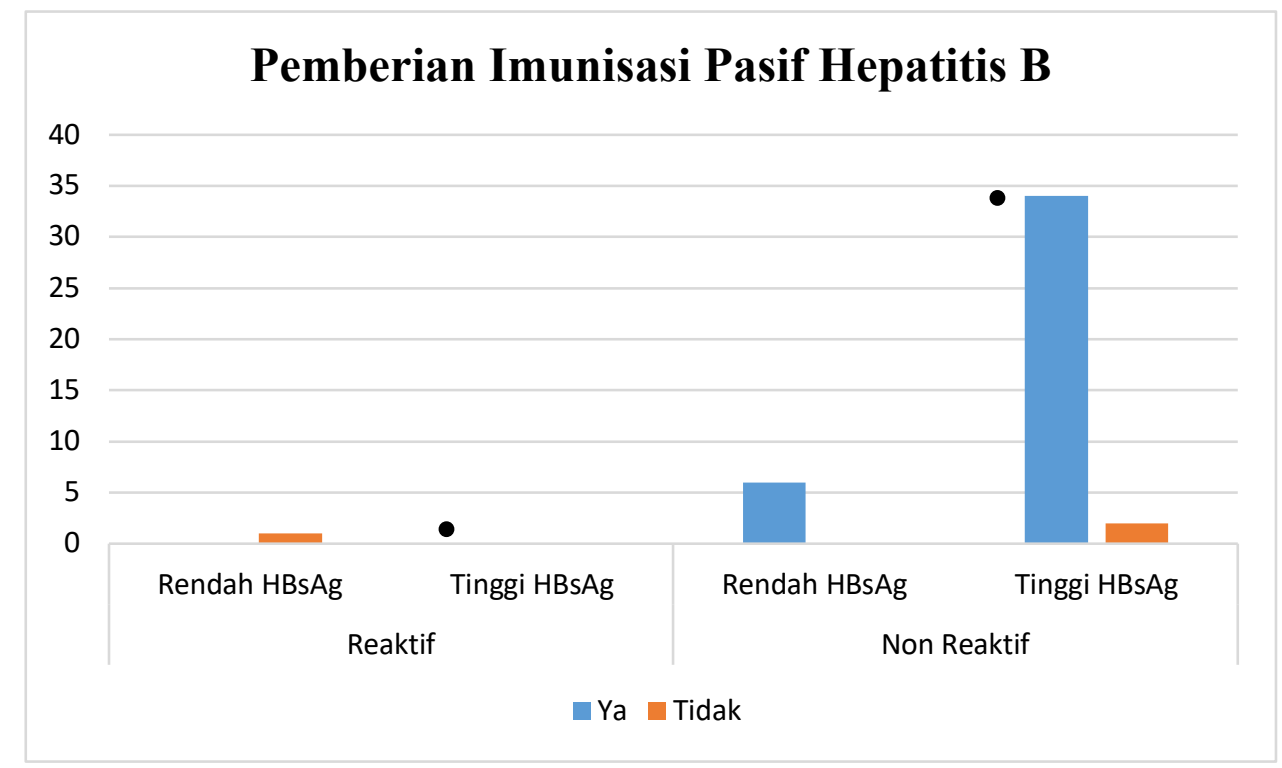

Gambar 1. Diagram jumlah Pemberian imunisasi pasif hepatitis B (HBIG) dengan status HBsAg pasca imunisasi saat anak usia $>9$ bulan yang dilahirkan dari ibu dengan HBsAg positif di 4 wilayah puskesmas di Surabaya tahun 2017

Imunisasi pasif hepatitis B (HBIG) diberikan dalam 12 jam setelah bayi lahir. Hasil pengumpulan data didapatkan hampir seluruh bayi $(91,1 \%)$ pada 4 wilayah puskesmas terkait melakukan imunisasi HBIG (Hepatitis B Immunoglobulin) dalam 12 jam setelah lahir dan dinyatakan non reaktif terhadap HBsAg saat anak berusia $>9$ bulan. Dalam rincian 6 bayi pada wilayah rendah HBsAg dan 34 bayi 
pada wilayah tinggi HBsAg melakukan imunisasi pasif hepatitis B (HBIG) dan dinyatakan non reaktif saat mereka berusia $>9$ bulan.

Namun terdapat 1 bayi $(1,8 \%)$ di wilayah rendah HBsAg tidak melakukan imunisasi HBIG dan dinyatakan reaktif terhadap HBsAg pasca imunisasi saat anak berusia $>9$ bulan. Lain hal pada 2 anak $(3,6 \%)$ di wilayah tinggi HBsAg yang dinyatakan non reaktif terhadap HBsAg saat berusia $>9$ bulan meskipun mereka tidak melakukan imunisasi HBIG saat lahir.

\section{Pemberian dan Kepatuhan Imunisasi Pasif hepatitis B (HBIG)}

Imunisasi HBIG termasuk dalam imunisasi pasif yang suntikannya akan memberikan efek pembuatan antibodi yang bertujuan memberikan kekebalan secara langsung sehingga tubuh tidak harus memproduksi sendiri zat aktif untuk kekebalan tubuhnya (Surya,2017). Efektifitas imunisasi HBIG ini mencapai 85\%95\% yang akan memberikan perlindungan sesegera mungkin meskipun hanya untuk jangka 3-6 bulan (IDAI, 2011). Pada penelitian yang dilakukan di 4 wilayah puskesmas di Kota Surabaya tahun 2017 didapatkan 5 bayi (8,9\%) tidak melakukan imunisasi pasif HBIG. Hasil pemeriksaan menyatakan 1 dari 5 bayi $(1,8 \%)$ tersebut dinyatakan reaktif terhadap HBsAg saat berusia $>9$ bulan karena saat lahir ibu menolak bayinya diberikan imunisasi pasif HBIG meskipun bayi tersebut melakukan imunisasi aktif HB-0/HB-1/HB-2/HB-3 tepat waktu. Hasil yang sama juga ditunjukkan dalam penelitian Gong \& Liu (2017) yang menyatakan bahwa HBIG dapat memproduksi antibodi anti-HBs dalam beberapa jam setelah disuntikkan. Suntikkan HBIG dapat mencegah penularan hepatitis B transmisi mother-to-infant dengan efektifitas $85 \%-95 \%$ bila dikombinasikan dengan imunisasi aktif hepatitis B lengkap.

\section{SIMPULAN DAN SARAN}

Hasil penelitian ini dapat disimpulkan bahwa hampir seluruh bayi $(91,1 \%)$ yang lahir dari ibu dengan HBsAg positif melakukan imunisasi pasif hepatitis B (HBIG) dengan tepat waktu. Didapatkan status HBsAg anak yang dilahirkan dari ibu dengan HBsAg positif saat usia $>9$ bulan pasca imunisasi yakni sebagian besar (75\%) non reaktif terhadap HBsAg dan sebagian kecil $(1,8 \%)$ anak dinyatakan reaktif terhadap HBsAg. Diharapkan pemegang kebijakan program dapat lebih 
memprioritaskan dan menyukseskan program kesehatan di Indonesia khususnya imunisasi hepatitis B (pasif dan aktif) sehingga dapat menurunkan angka kejadian kasus hepatitis B di kota Surabaya. Diharapkan pemegang kebijakan program dapat mewajibkan fasilitas kesehatan untuk ibu hamil melakukan tes seperti status HBeAg dan kadar anti-HBs.

\section{DAFTAR PUSTAKA}

Demirjian A; \& Levy O. (2009). Mini-Review: Safety and Efficacy of Neonatal Vaccination. European Journal of Immunology, 39(1), pp. 36-46. https://doi.org/10.1002/eji.200838620

Dinas Kesehatan Kota Surabaya. (2017) Profil Kesehatan Kota Surabaya Tahun 2017. (Pembina: Febria Rachmanita) Surabaya: Dinas Kesehatan Pemerintah Kota Surabaya.

Dinas Kesehatan Provinsi Jawa Timur. (2016). Profil Kesehatan Provinsi Jawa Timur Tahun 2016. (Pembina: Kohar Hari Santoso). Surabaya: Dinas Kesehatan Provinsi Jawa Timur

El-asheer OM; Darwish MM; Abdou MA; \& Saad K. (2015). Immunogenicity of Recombinant Hepatitis B Vaccine Among Routinely Vaccinated Healthy and Chronically Ill Children. Gastroenterolgy Research, 8(3-4), pp. 222227

Gong J; \& Liu X. (2018). Effect of HBIG Combined with Hepatitis B Vaccine on Blocking HBV Transmission Between Mother and Infant and Its Effect on Immune Cells. Experimental And Therapeutic Medicine, 15(1), pp. 919-923. https://doi.org/10.3892/etm.2017.5474

Lusida MI; Juniastuti; Yano Y. (2016). Current Hepatitis B Virus Infection Situation In Indonesia and Its Genetic Diversity. World Journal Gastroenterology, 22 (32), 7264.

Ranuh, IGNG; Suyitno H; Hadinegoro SRSH; Kartasasmita CB; Ismoedijanto; Ko S. (2011). Pedoman Imunisasi Anak di Indonesia. Edisi 4. Jakarta: Badan Penerbit Ikatan Dokter Anak Indonesia, pp. 256-263.

Yahyapour Y; Karimi M; Molaei H; Khoddami E; \& Mahmoudi M. (2011). Activepassive Immunization Effectiveness Against Hepatitis B Virus in Children Born to HBsAg Positive Mothers in Amol, North of Iran. Oman Medical Journal, 26(6), pp. 399-403

Yano Y; Utsumi T; Lusida MI; \& Hayashi Y. (2015). Hepatitis B Virus Infection in Indonesia. World Journal Gastroenterology, 21 (38), 10714-10720. doi: 10.3748/wjg.v21.i38.1071 